BNL-108269-2015-JA

\title{
Biomass-Derived High-Performance Tungsten-Based Electrocatalysts on Graphene for Hydrogen Evolution
}

\author{
Fanke Meng, ${ }^{a}$ Enyuan $\mathrm{Hu},{ }^{a}$ Lihua Zhang, ${ }^{b}$ Kotaro Sasaki, ${ }^{a}, *$ \\ James T. Muckerman, ${ }^{a}$ and Etsuko Fujita ${ }^{a} *$ \\ ${ }^{a}$ Chemistry Department, Brookhaven National Laboratory, Upton, New York, 11973, USA. \\ ${ }^{b}$ Center for Functional Nanomaterials, Brookhaven National Laboratory, Upton, New York \\ 11973, USA
}

\begin{abstract}
We report a new class of highly active and stable tungsten-based catalysts to replace noble metal materials for the hydrogen evolution reaction (HER) in an acidic electrolyte. The catalyst is produced by heating an earth-abundant and low-cost mixture of ammonium tungstate, soybean powder and graphene nanoplatelets (WSoyGnP). The catalyst compound consists of tungsten carbide $\left(\mathrm{W}_{2} \mathrm{C}\right.$ and $\left.\mathrm{WC}\right)$ and tungsten nitride (WN) nanoparticles decorated onto graphene nanoplatelets. The catalyst demonstrates an overpotential $\left(\eta_{10}\right.$, the potential at a current density of $10 \mathrm{~mA} \mathrm{~cm}^{-2}$ ) of $0.105 \mathrm{~V}$, which is the smallest among tungsten-based HER catalysts in acidic media. The coupling with graphene significantly reduces the charge transfer resistance and increases the active surface area of the product, which are favorable for enhancing the HER activity. Therefore, the approach of employing biomass and other less expensive materials as precursors for the production of catalysts with high HER activity provides a new path for the design and development of efficient catalysts for the hydrogen production industry.
\end{abstract}

\section{Introduction}

In comparison with fossil fuels, hydrogen is a green source of energy that does not generate carbon dioxide during direct combustion or in hydrogen fuel cells that could play an important role in meeting the growing energy needs of the world. ${ }^{1-4}$ One attractive approach to generating hydrogen fuel is via the electrocatalytic hydrogen evolution reaction (HER) in splitting water. ${ }^{4-8}$ In this scenario, developing efficient and durable electrocatalysts is extremely critical. Until now, Pt-group metals (Pt, Ir, Ru, Rh, Pd) have been the most efficient catalysts for 
the HER for the reason that, as a typical example, Pt exhibits an optimal hydrogen binding energy to balance the hydrogen adsorption and release on the catalyst surface. ${ }^{9-11}$ However, its precious nature and scarcity hinder scale-up production and market penetration of the noble metals to satisfy the goal of competitive hydrogen production $\left(\$ 2.00-3.00 \mathrm{~kg}^{-1}\right)$ of the U.S. Department of Energy. ${ }^{12}$ For this reason, development of noble-metal-free materials to substitute for Pt-group catalysts to lower cost without a significant loss in catalytic activity is strongly motivated. Recently, a family of tungsten-based materials $\left(\mathrm{WS}_{2}, \mathrm{WSe}_{2}, \mathrm{WP}, \mathrm{WC}, \mathrm{W}_{\mathrm{x}} \mathrm{C} \text {, etc. }\right)^{13-24}$ was extensively investigated as effective electrocatalysts for the HER because of favorable structural and electronic properties. ${ }^{25,26}$ For example, as one of the layered transition-metal dichalcogenides $\left(\mathrm{MX}_{2}: \mathrm{M}=\mathrm{Mo}\right.$ or $\mathrm{W}, \mathrm{X}=\mathrm{S}$ or $\left.\mathrm{Se}\right), \mathrm{WS}_{2}$ has graphite-like structure, consisting of two dimensional S-W-S layers that are hexagonally stacked by weak van der Waals interactions. ${ }^{1,8}$ Electrons prefer to move along the basal plane of the S-W-S layers towards the edge sites that are favorable for the catalytic HER. The $\mathrm{WS}_{2}$ catalyst showed reasonably good electrocatalytic activity with an overpotential of $140-260 \mathrm{mV}$ at a current density of $10 \mathrm{~mA} \mathrm{~cm}^{-2}$ ) $\left(\eta_{10}\right)$, but suffered from somewhat limited durability. 3,6,8,13,16 More excitingly, Levy and Boudart discovered "Pt-like" catalytic performance of the tungsten carbide phases, which is an alternative path for development of new noble-metal-free catalysts. ${ }^{25}$ The tungsten carbides performing similarly to $\mathrm{Pt}$ in catalytic behavior resulted from the establishment of a "Pt-like" $d$-band electronic density of states by intercalation of carbon atoms into the tungsten lattice. ${ }^{26}$ Consequently, the tungsten carbides demonstrated effective surface catalysis in many research domains, for example, cellulose conversion, methanol oxidation, water reduction, etc. ${ }^{24,35,36}$ In addition, high tolerance to $\mathrm{CO}, \mathrm{N}$ and $\mathrm{S}$ poisoning is another meritorious property of the tungsten carbides for replacement of precious metals in renewable energy systems, such as fuel cells and electrolyzers. $^{20,27,28}$

It is therefore of considerable interest to fabricate low-cost and highly efficient tungstenbased catalysts for hydrogen fuel production. Although the tungsten carbides showed high HER performance, the solitary tungsten carbides exhibited limited durability in long-term catalytic reactions unless coupled with $\mathrm{WN}$ as a stabilizer. ${ }^{4}$ In our previous research, we discovered highly efficient HER composite catalysts consisting of $\mathrm{Mo}_{2} \mathrm{C}$ and $\mathrm{Mo}_{2} \mathrm{~N}$ by sintering soybean powder and ammonium molybdate. ${ }^{29}$ The soybean provided $\mathrm{C}$ and $\mathrm{N}$ for forming both $\mathrm{Mo}_{2} \mathrm{C}$ and $\mathrm{Mo}_{2} \mathrm{~N}$ in the catalysts, in which the $\mathrm{Mo}_{2} \mathrm{~N}$ imparted a strong stabilizing effect against corrosion in acids. 
Thus, the long term durability of the HER by the MoSoy catalysts was significantly enhanced. Inspired by our previous work on biomass-derived MoSoy catalysts, ${ }^{29}$ herein we report the synthesis of WSoy catalysts comprising tungsten carbides ( $\mathrm{WC}$ and $\mathrm{W}_{2} \mathrm{C}$ ) and tungsten nitride (WN) decorated onto graphene for the HER by sintering abundant and environmentally friendly precursors, ammonium tungstate (AMT), soybean powder and graphene nanoplatelets (GnP). In the composite product, tungsten carbides and $\mathrm{WN}$ worked as catalysts and catalysis stabilizer, respectively, in the HER. Graphene acted as a good catalyst support because of two advantageous properties: first, graphene is able to impede particle growth of the catalyst, which is beneficial to obtain more reaction sites on the catalyst surface $;^{30,31}$ and second, owning to the high electron mobility $\left(>15000 \mathrm{~cm}^{2} \mathrm{~V}^{-1} \mathrm{~S}^{-1}\right)$ and graphene's inherent flexibility, it is a good medium for establishing contact and improving conduction between catalyst particles and electrodes. $^{31,32}$ With optimization of the contents of the graphene and soybean powder in the precursors, the composite product, WSoy $_{0.7} \mathrm{GnP}_{1.0}$ was found to be the most highly active HER catalyst in both catalytic activity and stability among all $\mathrm{WSoy}_{\mathrm{x}} \mathrm{GnP}_{\mathrm{y}}$ electrocatalysts examined. This paper thereby introduces an easy and inexpensive method to synthesize high-performance biomass-derived HER catalysts.

\section{Results and discussion}
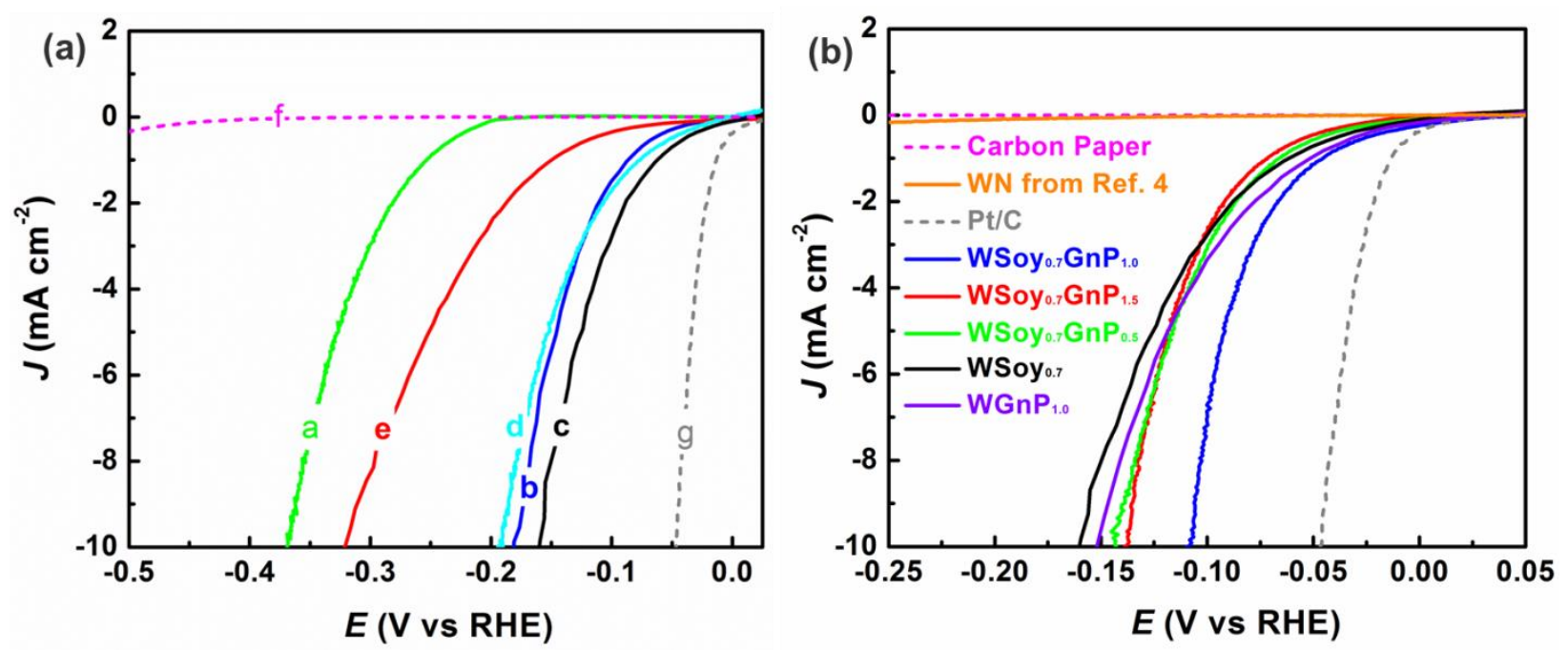

Figure 1. (a) Polarization curves of $\operatorname{WSoy}_{0.2}$ (a), $\operatorname{WSoy}_{0.5}$ (b), $\operatorname{WSoy}_{0.7}$ (c), $\operatorname{WSoy}_{1.0}$ (d), and $\operatorname{WSoy}_{2.0}$ (e) samples, along with carbon paper without catalyst (f) and commercial Pt/C (g). (b) Polarization curves of WSoy ${ }_{0.7}$, 
WSoy $_{0.7} \mathrm{GnP}_{0.5}$, WSoy $0.7 \mathrm{GnP}_{1.0}$, WSoy $0.7 \mathrm{GnP}_{1.5}$, and $\mathrm{WGnP}_{1.0}$ samples, along with carbon paper without catalyst and commercial $\mathrm{Pt} / \mathrm{C}$. Also shown is the polarization curve of $\mathrm{WN}$ with a loading of $2.2 \mathrm{mg} \mathrm{cm}^{-2}$ from our previous research reported in reference 4. All the polarization curves were obtained in a $\mathrm{H}_{2}$-purged $0.1 \mathrm{M} \mathrm{HClO}_{4}$ aqueous solution with a scan rate of $2 \mathrm{mV} \mathrm{s}^{-1} .10 \mathrm{mg}$ of the samples were loaded onto each carbon paper electrode $\left(1 \mathrm{~cm}^{2}\right)$. The loadings of $\mathrm{W}_{2} \mathrm{C}, \mathrm{WC}$, and $\mathrm{WN}$ for $\mathrm{WSoy}_{0.7} \mathrm{GnP}_{1.0} \mathrm{WSoy}_{0.7}$, and $\mathrm{WGnP}_{1.0}$ are listed in Table 1 . The Pt loading on each electrode was $2 \mathrm{mg} \mathrm{cm}^{-2}$.

Our methodology began with synthesis of a series of $\operatorname{WSoy}_{x}(x=0.2,0.5,0.7,1.0$ and 2.0) to optimize the mass ratio of AMT and soybean powder. The detailed synthesis method is described in the Experimental section of the Supporting Information (SI). The electrochemical behavior for the HER of a series of the WSoy $_{x}$ catalysts is shown in Figure 1(a). The overpotential $\left(\eta_{10}\right)$ was used to evaluate the HER activity of the electrocatalysts. ${ }^{4,8,9}$ Among the five samples, the $\mathrm{WS}_{0.7}$ showed the best HER performance with the smallest $\eta_{10}$ of $0.16 \mathrm{~V}$. Then, based on the $\mathrm{WS}_{0.7}$ composition, three other catalysts $\left(\mathrm{WSoy}_{0.7} \mathrm{GnP}_{0.5}\right.$, WSoy ${ }_{0.7} \mathrm{GnP}_{1.0}$ and $\mathrm{WSoy}_{0.7} \mathrm{GnP}_{1.5}$ ) with different graphene content were fabricated using the same method as described in the SI. As shown in Figure 1(b), all the WSoy ${ }_{0.7} \mathrm{GnP}_{\mathrm{y}}$ samples had a smaller $\eta_{10}$ than either $\mathrm{WSoy}_{0.7}$ or $\mathrm{WGnP}_{1.0}$ in the polarizationcurves. This indicates that both soybean and graphene can improve the electrocatalytic HER performance of the catalysts. Among the three catalysts of the $\mathrm{WSoy}_{0.7} \mathrm{GnP}_{0.5}$, WSoy ${ }_{0.7} \mathrm{GnP}_{1.0}$ and $\mathrm{WSoy}_{0.7} \mathrm{GnP}_{1.5}$ series, the $\mathrm{WSoy}_{0.7} \mathrm{GnP}_{1.0}$ showed significantly superior HER activity with a much smaller $\eta_{10}$ of $0.105 \mathrm{~V}$ than the other two catalysts. We note that the bare carbon paper without catalyst did not show any HER activity as shown in both Figure 1(a) and 1(b). 


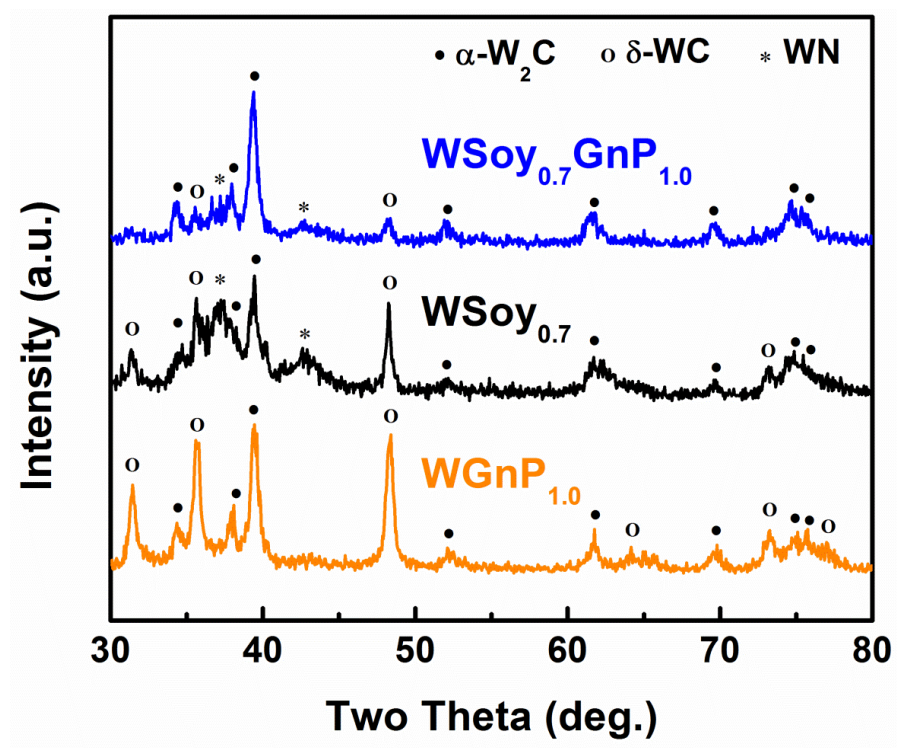

Figure 2. XRD patterns of the $\mathrm{WSoy}_{0.7} \mathrm{GnP}_{1.0}, \mathrm{WSoy}_{0.7}$ and $\mathrm{WGnP}_{1.0}$ samples. The assignments of the diffraction peaks are included (solid circle: $\alpha-\mathrm{W}_{2} \mathrm{C}$, hollow circle: $\delta$-WC, asterisk, WN).

To understand the effect of phase compositions of the catalysts on the HER, X-ray Diffraction (XRD) was employed to analyze three catalysts (Figure 2). The $\mathrm{WGnP}_{1.0}$ catalysts consist of two tungsten carbides, $\alpha-\mathrm{W}_{2} \mathrm{C}$ (JCPDS: 35-0776) and $\delta$-WC (JCPDS: 72-0097) without tungsten nitride because no soybean powder was present in the precursor mixture for supplying nitrogen. Both the $\mathrm{WS}_{0.7} \mathrm{GnP}_{1.0}$ and the $\mathrm{WS}_{0.7}$ contain three tungsten compounds, $\alpha-\mathrm{W}_{2} \mathrm{C}, \delta-\mathrm{WC}$, and WN (JCPDS: 65-2898). Phase fractions of the catalysts were obtained through Rietveld refinement (see SI for detailed information) of the XRD spectra, as shown in Figure S1 and Table S1. To obtain the mass content of each compound in the catalysts, the samples were analyzed with thermogravimetric analysis (TGA) by heating up to $950{ }^{\circ} \mathrm{C}$ with a temperature ramping rate of $20^{\circ} \mathrm{C} \mathrm{min}^{-1}$ in oxygen, and then the temperature was kept at $950{ }^{\circ} \mathrm{C}$ for an extra 10 min to ensure the product was completely tungsten oxide $\left(\mathrm{WO}_{3}\right)$. The eventual $\mathrm{WO}_{3}$ content of the $\mathrm{WSoy}_{0.7} \mathrm{GnP}_{1.0}$, WSoy ${ }_{0.7}$ and $\mathrm{WGnP}_{1.0}$ was $23 \%, 58 \%$, and $72 \%$, respectively, by weight normalization in Figure S2. With a total $10 \mathrm{mg}$ sample loaded onto the carbon paper electrode, the masses of each compound are able to be calculated by using both $\mathrm{WO}_{3}$ content and phase fractions, ${ }^{4}$ which are shown in Table 1. 
Table 1. Mass contents of the phases in the $\mathrm{WSoy}_{0.7} \mathrm{GnP}_{1.0}$, $\mathrm{WSoy}_{0.7}$ and $\mathrm{WGnP}_{1.0}$ samples on each electrode.

\begin{tabular}{cccc}
\hline Sample & $\begin{array}{c}\mathrm{WSoy}_{0.7} \mathrm{GnP}_{1.0} \\
\left(\mathrm{mg} \mathrm{cm}^{-2}\right)\end{array}$ & $\begin{array}{c}\text { WSoy }_{0.7} \\
\left(\mathrm{mg} \mathrm{cm}^{-2}\right)\end{array}$ & $\begin{array}{c}\mathrm{WGnP}_{1.0} \\
\left(\mathrm{mg} \mathrm{cm}^{-2}\right)\end{array}$ \\
\hline $\mathrm{W}_{2} \mathrm{C}$ & 1.41 & 2.64 & 2.22 \\
$\mathrm{WC}$ & 0.34 & 2.76 & 2.61 \\
$\mathrm{WN}$ & 0.15 & 0.60 & -- \\
$\mathrm{GnP}+$ carbonizations & 8.10 & 4.00 & 5.17 \\
\hline
\end{tabular}

The mass of the tungsten carbides in the $\mathrm{WSoy}_{0.7} \mathrm{GnP}_{1.0}\left(\mathrm{~W}_{2} \mathrm{C}, 1.41 \mathrm{mg}\right.$; WC, $\left.0.34 \mathrm{mg}\right)$ was much smaller than that in the $\mathrm{WSoy}_{0.7}\left(\mathrm{~W}_{2} \mathrm{C}, 2.64 \mathrm{mg}\right.$; WC, $\left.2.76 \mathrm{mg}\right)$ and $\mathrm{WGnP}_{1.0}\left(\mathrm{~W}_{2} \mathrm{C}, 2.22\right.$ $\mathrm{mg}$; WC, $2.61 \mathrm{mg}$ ). This was due to a smaller amount of AMT in the precursor mixture of the WSoy $_{0.7} \mathrm{GnP}_{1.0}$, which was also observed in the $\mathrm{Mo}_{1}$ Soy/RGO samples. ${ }^{29}$ For example, the $33 \%$ ammonium molybdate in the precursor of $\mathrm{Mo}_{1}$ Soy/RGO led to $0.47 \mathrm{mg} \mathrm{Mo}_{2} \mathrm{C}$, however, $50 \%$ ammonium molybdate led to $1.40 \mathrm{mg} \mathrm{Mo} 2 \mathrm{C}$ in $\mathrm{Mo}_{1} \mathrm{Soy}^{29}$ Our previous study ${ }^{4}$ and a later study by Esposito et al. ${ }^{23}$ showed that $\mathrm{W}_{2} \mathrm{C}$ exhibited slight higher catalytic activity for the HER and a smaller Tafel slope than WC. However, WN more likely functioned as a stabilizer in the composite catalyst with considerably less catalytic HER activity than either the $\mathrm{W}_{2} \mathrm{C}$ or the WC. ${ }^{4}$ Comparing the $\mathrm{WSoy}_{0.7} \mathrm{GnP}_{1.0}$ and $\mathrm{WS}_{0.7}$ compositions in Table 1, both catalysts contained $\mathrm{W}_{2} \mathrm{C}$, WC and $\mathrm{WN}$. The tungsten carbides were even more abundant in the $\mathrm{WSoy}_{0.7}$ than in the WSoy $_{0.7} \mathrm{GnP}_{1.0}$, however, the $\eta_{10}$ of the $\mathrm{WSoy}_{0.7}(0.160 \mathrm{~V})$ was larger than that of the WSoy $_{0.7} \mathrm{GnP}_{1.0}(0.105 \mathrm{~V})$. Actually, the graphene played an important role in the $\mathrm{WSoy}_{0.7} \mathrm{GnP}_{1.0}$ to function as a metal-like connector and carrier to establish more efficient charge transfer between the catalyst particles and the electrode. ${ }^{30-32}$ Therefore, the reason that the $\mathrm{WSoy}_{0.7} \mathrm{GnP}_{1.0}$ performed better in the HER than the WSoy $_{0.7}$ even with less tungsten carbide content, is considered to stem from the interaction of the graphene-catalyst interface. These details are discussed below.

On the other hand, the $\mathrm{WS}_{0.7} \mathrm{GnP}_{1.0}$ catalyst, despite containing a very small amount of $\mathrm{WN}$, showed a higher HER activity $\left(\eta_{10}\right.$ of $\left.0.151 \mathrm{~V}\right)$ than that of the $\mathrm{WGnP}_{1.0}$ (Figure 1 ), although the tungsten carbide content in $\mathrm{WSoy}_{0.7} \mathrm{GnP}_{1.0}$ was lower than that in $\mathrm{WGnP}_{1.0}$ (Table 1). We note that $\mathrm{WGnP}_{1.0}$ contains no $\mathrm{WN}$ phase. In our previous research, solitary $\mathrm{WN}$ 
exhibited only a slight activity towards the HER, as shown in Figure 1(b). ${ }^{4}$ Thus, the result of the present study suggests that in addition to acting as a stabilizer, WN may impart a synergistic effect to enhance the HER activity of the tungsten carbides even though the WN content involved is fairly small. There would be an electronic coupling between the nitride and carbides, although the detailed mechanism has yet to be explained but is being pursued.

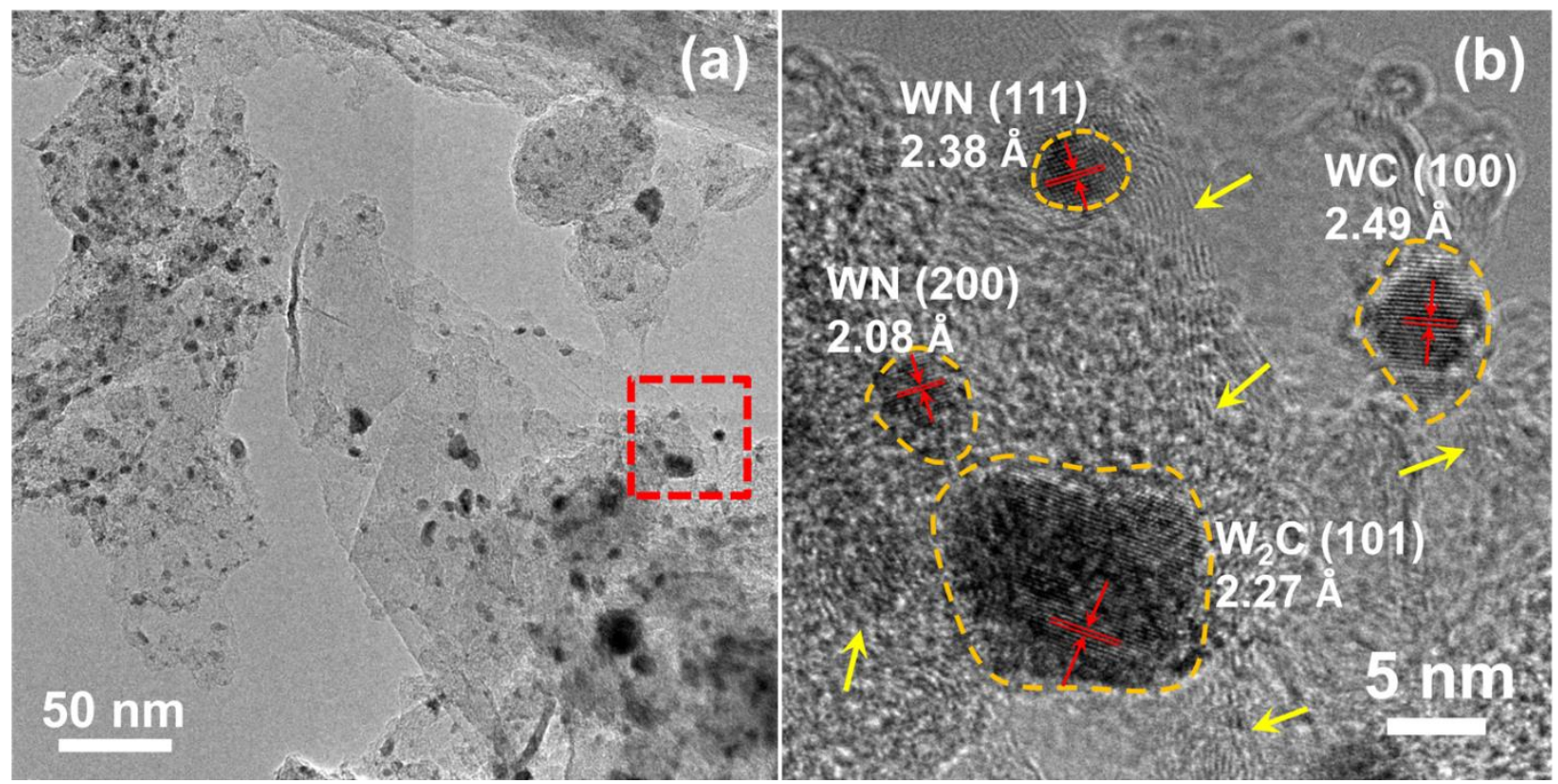

Figure 3. (a) TEM image of the $\mathrm{WSoy}_{0.7} \mathrm{GnP}_{1.0}$, and (b) HRTEM image of the enlarged area in the red box in (a)

The morphology of the $\mathrm{WSoy}_{0.7} \mathrm{GnP}_{1.0}$ is shown in the transmission electron microscope (TEM) images in Figure 3, which demonstrate the configuration and distribution of the various components. In Figure 3(a), the graphene nanoplatelets exhibit a size of 100-200 nm decorated by many black spots with a size between 5 and $20 \mathrm{~nm}$. In order to clearly show the composition of the black spots, a high resolution transmission electron microscope (HRTEM) image is shown in Figure 3(b). Four nanoparticles are shown on the graphene nanoplatelets and are indicated by the dashed orange lines. The yellow arrows indicate the edges of the flexible layered structure of the nanoplatelets, while the red arrows identify the crystal facets on the surface of the nanoparticles. The largest nanoparticle is $\mathrm{W}_{2} \mathrm{C}$ with a lattice spacing of $2.27 \AA$, which is the (101) facet according to the standard JCPDS: 35-0776. In addition, the WC shows a clear orientation of (100) with a spacing of $2.49 \AA$ (JCPDS: 72-0097), and the other two small WN 
particles exhibit crystal facets of (111) and (200) with spacings of $2.38 \AA$ and $2.08 \AA$ (JCPDS: 65-2898), respectively. The TEM and HRTEM images of the $\mathrm{WGnP}_{1.0}$, and $\mathrm{WS}_{0.7}$ catalysts are presented in Figure $\mathrm{S} 3$, in which the $\mathrm{WGnP}_{1.0}$ shows similar morphology to that of the WSoy $_{0.7} \mathrm{GnP}_{1.0}$ with decoration by $\mathrm{W}_{2} \mathrm{C}$ and $\mathrm{WC}$ on the graphene nanoplatelets. The size of the tungsten carbides in the $\mathrm{WGnP}_{1.0}$ sample is about $15 \mathrm{~nm}$ in Figures S3(b) and S3(c). However, most of the particles of the WSoy 0.7 catalyst grew up to $\sim 20-50 \mathrm{~nm}$ as shown in Figure S3(d). The much larger particle size of the $\mathrm{WSoy}_{0.7}$ than of the $\mathrm{WSoy}_{0.7} \mathrm{GnP}_{1.0}$ and the $\mathrm{WGnP}_{1.0}$ is attributed to the absence of graphene nanoplatelets. ${ }^{30,31}$ Thus, by comparison of the morphologies of the $\mathrm{WSoy}_{0.7}$ and $\mathrm{WSoy}_{0.7} \mathrm{GnP}_{1.0}$, two merits of the graphene for enhancement of the electrocatalytic performance were demonstrated. First, graphene hindered particle growth of the tungsten carbides and nitrides, leading to more reaction sites on the catalyst surface for the HER. Second, graphene functioned as a good medium for charge transfer between the catalyst and electrodes. Given that the catalyst particles were grown on the graphene, and the catalysts were not directly attached onto the electrode, the electrons were still able to move from the electrode to the catalyst particles owing to the excellent conductivity and charge mobility in graphene. Without graphene, some electron transfer pathways are hindered by the interfaces of the particles because the interfaces can act as recombination sites for the charges. ${ }^{2,32}$ Therefore, fewer electrons are used by the catalyst for the HER in the $\mathrm{WSoy}_{0.7}$ than that in the $\mathrm{WSoy}_{0.7} \mathrm{GnP}_{1.0}$. 


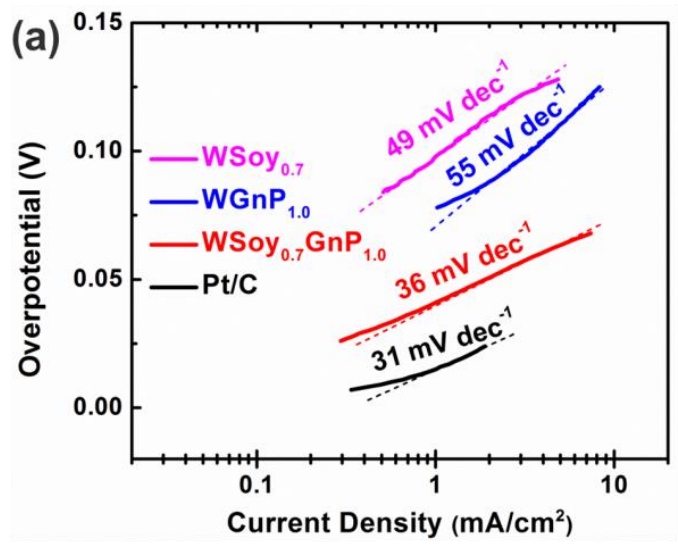

(b)
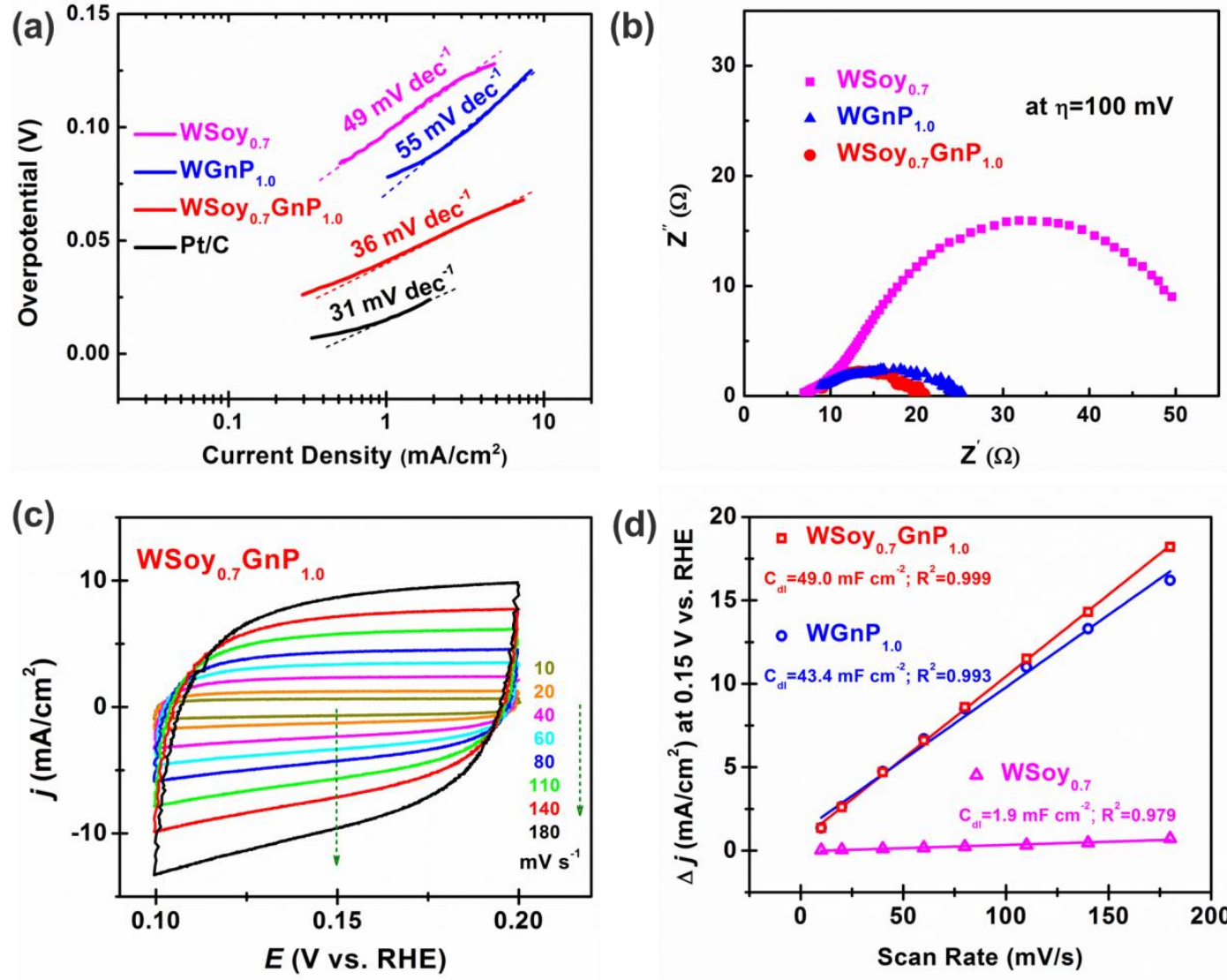

(d)

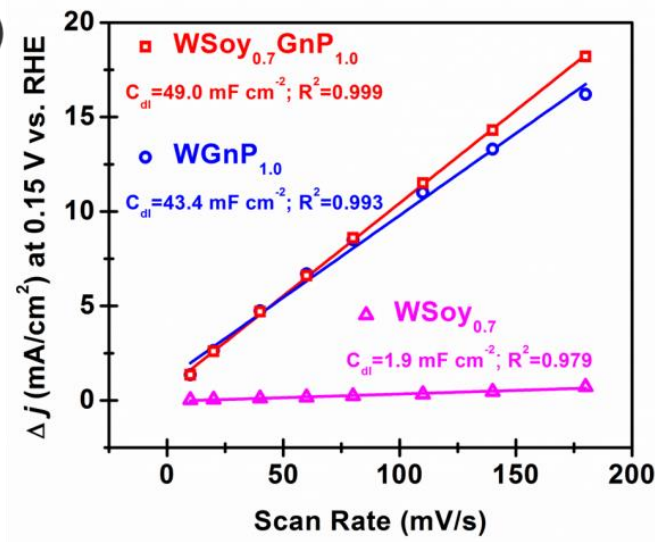

Figure 4. Electrochemical measurements on the catalysts: (a) Tafel plots; (b) electrochemical impedance spectroscopy (EIS) at a bias of $100 \mathrm{mV}$ of $\mathrm{WSoy}_{0.7} \mathrm{GnP}_{1.0}$, WSoy ${ }_{0.7}$ and $\mathrm{WGnP}_{1.0}$; (c) cyclic voltammetry curves of WSoy $_{0.7} \mathrm{GnP}_{1.0}$ in the region of 0.1-0.2 V; and (d) linear fitting of the capacitive currents of $\mathrm{WSoy}_{0.7} \mathrm{GnP}_{1.0}, \mathrm{WSoy}_{0.7}$ and $\mathrm{WGnP}_{1.0}$ vs. scan rate to obtain $C_{\mathrm{dl}}$ of each catalyst.

Table 2. Tafel slope and exchange current density calculated from the Tafel plots of the catalysts

\begin{tabular}{ccc}
\hline Catalyst & $\begin{array}{c}\text { Tafel Slope } \\
\left(\mathrm{mV} \mathrm{dec}^{-1}\right)\end{array}$ & $\begin{array}{c}\text { Exchange Current Density } \\
\left(\mathrm{mA} \mathrm{cm}^{-2}\right)\end{array}$ \\
\hline WSoy $_{0.7} \mathrm{GnP}_{1.0}$ & 36 & 0.063 \\
WSoy $_{0.7}$ & 49 & 0.011 \\
WGnP $_{1.0}$ & 55 & 0.040 \\
$\mathrm{Pt} / \mathrm{C}$ & 31 & 0.344
\end{tabular}


Electrochemical performance of the catalysts was evaluated as shown in the Figure 4. Tafel plots in Figure 4(a) were employed to calculate two indicators (Tafel slope and exchange current density) for characterizing the electrochemical HER process of the catalysts as shown in Table 2. In acidic aqueous media, the HER process is described in two steps according to different models of the two-electron reaction. ${ }^{6,8,9}$ First, the Volmer reaction (also called the "discharge step") in which the combination of electrons and adsorbed protons on the active sites of the catalyst takes place, resulting in surface-bound hydrogen atoms. Then, the hydrogen molecules are released by electrochemical desorption (Heyrovsky reaction), or by recombination of hydrogen atoms absorbed on the catalysts surface (Tafel reaction). ${ }^{6,9}$ The slope of the Tafel plot of the $\mathrm{Pt} / \mathrm{C}$ catalyst was $31 \mathrm{mV} \mathrm{dec}^{-1}$, which typifies the recombination of adsorbed hydrogen as the rate-limiting step. ${ }^{21}$ However, the $\mathrm{WSoy}_{0.7}$ and $\mathrm{WGnP}_{1.0}$ catalysts had larger Tafel slopes of 49 and $55 \mathrm{mV} \mathrm{dec}{ }^{-1}$, respectively, suggesting a Volmer-Heyrovsky reaction with hydrogen electrochemical desorption as the rate-limiting step. ${ }^{3,9}$ The $\mathrm{WSoy}_{0.7} \mathrm{GnP}_{1.0}$ gave rise to a Tafel slope of $36 \mathrm{mV} \mathrm{dec}^{-1}$ over a small overpotential range, suggesting a possible pathway of the Volmer-Tafel reaction. ${ }^{3,9}$ Our WSoy ${ }_{0.7} \mathrm{GnP}_{1.0}$ sample has the smallest Tafel slope of any other tungsten-based catalysts reported to date in previous research, as shown in Table S2, 4,8,13,16,19,20,24 revealing that the $\mathrm{WS}_{0.7} \mathrm{GnP}_{1.0}$ showed faster proton discharge kinetics than the other counterparts. $^{5,29}$ Moreover, in Table 1, the exchange current density of the $\mathrm{WSoy}_{0.7} \mathrm{GnP}_{1.0}$ is determined to be $0.063 \mathrm{~mA} \mathrm{~cm}{ }^{-2}$ by linear fitting of the Tafel plot, which was larger than the other two catalysts. The significantly reduced Tafel slope and increased exchange current density of the $\mathrm{WSoy}_{0.7} \mathrm{GnP}_{1.0}$ reflects a lower energy barrier and more accessibility of the electrocatalytic HER, which is consistent with the decreased overpotential and increased current density in the polarization curve in Figure 1. In addition, electrochemical impedance spectroscopy (EIS) was employed to investigate the charge transfer resistance $\left(R_{\mathrm{ct}}\right)$ of the HER on the electrodes at a bias of $100 \mathrm{mV}$. In Figure 4(b), the Nyquist plots indicate the $R_{\mathrm{ct}}$ of the WSoy ${ }_{0.7} \mathrm{GnP}_{1.0}$, WSoy 0.7 and $\mathrm{WGnP}_{1.0}{ }^{4,8}$ The smaller $R_{\mathrm{ct}}$ of the $\mathrm{WSoy}_{0.7} \mathrm{GnP}_{1.0}$ and the $\mathrm{WGnP}_{1.0}$ of 10.7 and $15 \Omega$, respectively, than that of the $\mathrm{WSoy}_{0.7}$ of $\sim 50 \Omega$ indicates facile charge transfer towards the HER. Compared with other tungsten-based catalysts in Table $\mathrm{S} 2$, the $\mathrm{WS}_{0.7} \mathrm{GnP}_{1.0}$ ranked as one of the top-performing electrocatalysts. The $\mathrm{WSoy}_{0.7} \mathrm{GnP}_{1.0}$ showed smallest $\eta_{10}$ and Tafel slope among all the W-based catalysts, suggesting the lowest energy barrier and fastest proton discharging, which can also be supported by its smaller $R_{\mathrm{ct}}$ than most of the others. Its rate- 
limiting step is probably recombination (Tafel reaction) rather than electrochemical desorption (Heyrovsky reaction), reflecting "metal-like" behavior, which is consistent with the previous results of Pt-like surface catalysis performance. ${ }^{25}$

We also used the cyclic voltammetry (CV) method to evaluate the electrochemically active surface area of the catalysts, which demonstrated a proportional relationship with the double layer capacitance $\left(C_{\mathrm{dl}}\right)$ of the solid-liquid interface. ${ }^{8,16,33,34}$ In Figures $4(\mathrm{c})$ and S4, the potential range between $0.10 \mathrm{~V}$ and $0.20 \mathrm{~V}$ was selected to measure the accurate $C_{\mathrm{dl}}$ on the $\mathrm{CV}$ curves with exclusion of faradaic current. The $\mathrm{CV}$ was carried out at various scan rates $(10,20$, $40,60,80,110,140$, and $180 \mathrm{mV} \mathrm{s}^{-1}$ ). The difference between the positive and negative current density at the center of the potential range was obtained as a function of the scan rates as shown in Figure 4(d). The $C_{\mathrm{dl}}$ value of the catalysts was found to be equivalent to the slope of the plot of the half current density difference ( $\Delta j$ at $0.15 \mathrm{~V}$ vs. RHE in Figure 4(c)) over the scan rates. The WSoy ${ }_{0.7} \mathrm{GnP}_{1.0}$ and $\mathrm{WGnP}_{1.0}$ exhibited $C_{\mathrm{dl}}$ values of 49.0 and $43.4 \mathrm{mF} \mathrm{cm}^{-2}$, respectively, which was much larger than that of the WSoy $\left(1.9 \mathrm{mF} \mathrm{cm}^{-2}\right)$. The increase in the $C_{\mathrm{dl}}$ value by a factor of $c a .25$ arising from coupling graphene nanoplatelets with tungsten-based catalysts indicates a proliferation of catalytic sites of the catalyst/graphene composites. Since a very small $C_{\mathrm{dl}}$ value was obtained on graphene nanoplatelets only $\left(1.1 \mathrm{mF} \mathrm{cm}^{-2}\right)$ in Figure $\mathrm{S} 5$, the high double layer capacitances of the $\mathrm{WSoy}_{0.7} \mathrm{GnP}_{1.0}$ and $\mathrm{WGnP}_{1.0}$ are mostly attributed to an increase in surface area of the catalysts. Herein, the graphene plays a crucial role in hindering catalyst crystal growth, which serves as direct evidence of the much better electrocatalytic HER performance of the $\mathrm{WSoy}_{0.7} \mathrm{GnP}_{1.0}$ than that of the $\mathrm{WSoy}_{0.7}$ in Figure 1. Although the WSoy $_{0.7} \mathrm{GnP}_{1.0}$ and $\mathrm{WGnP}_{1.0}$ had similar electrochemically active surface areas, the $\mathrm{WGnP}_{1.0}$ showed less electrocatalytic activity for the HER. This is attributable to the absence of $\mathrm{WN}$ in the catalyst as we discussed above. Overall, as a catalyst carrier and conductive medium, the graphene can significantly boost the HER performance of the tungsten carbides by decreasing energy barrier, enhancing charge transfer and increasing the electrochemically active surface area of the catalyst. 

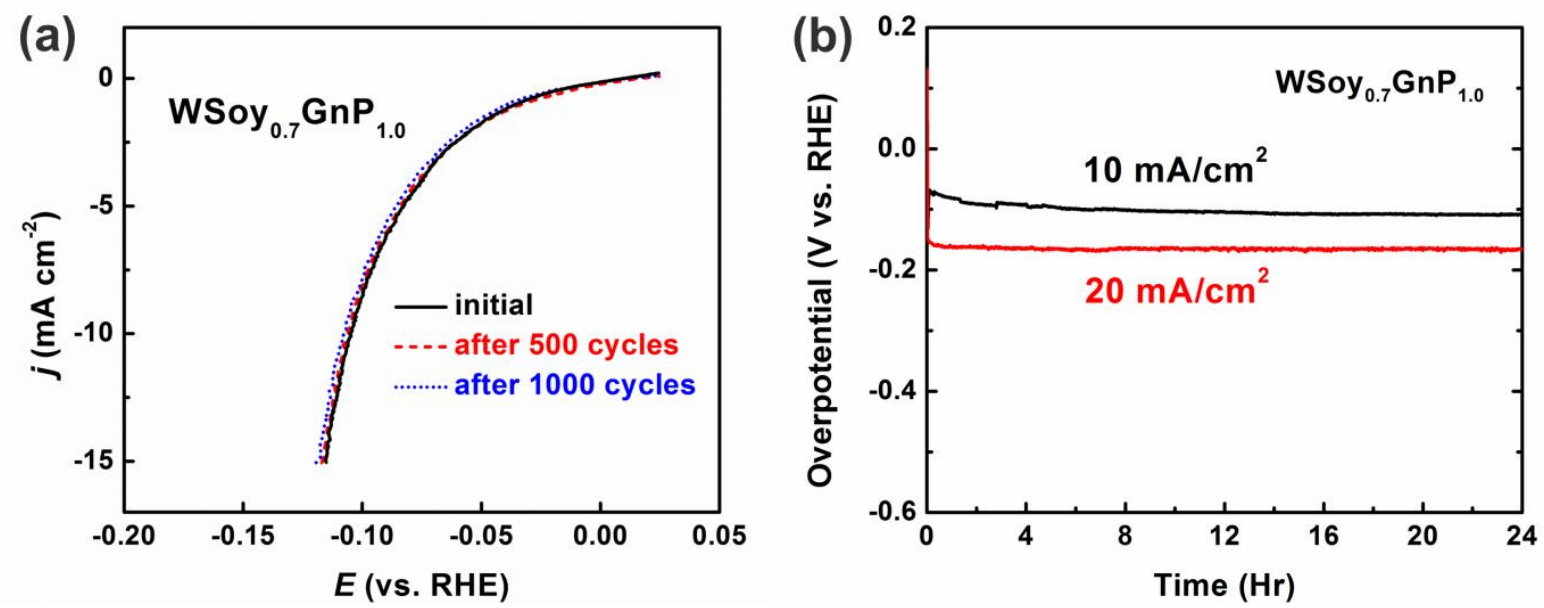

Figure 5. (a) Polarization curves of the $\mathrm{WSoy}_{0.7} \mathrm{GnP}_{1.0}$ before and after 500 and 1000 cycles at potentials between $0.5 \mathrm{~V}$ and $+0.3 \mathrm{~V}$ with a scan rate of $200 \mathrm{mV} \mathrm{s}^{-1}$; and (b) plots of overpotential vs. time for the WSoy ${ }_{0.7} \mathrm{GnP}_{1.0}$ electrode held for $24 \mathrm{hrs}$ at a constant current density of 10 and $20 \mathrm{~mA} \mathrm{~cm}{ }^{-2}$ (after $i R$ correction). Both electrochemical experiments were conducted in a $\mathrm{H}_{2}$-bubbled $0.1 \mathrm{M} \mathrm{HClO}_{4}$ aqueous solution.

Figures 5(a) and S6 show the stability performance of the $\mathrm{WSoy}_{0.7} \mathrm{GnP}_{1.0}, \mathrm{WSoy}_{0.7}$ and $\mathrm{WGnP}_{1.0}$, which was investigated by potential cycle tests at potentials between $-0.5 \mathrm{~V}$ and +0.3 V. In Figure 5(a), the three polarization curves of $\mathrm{WSoy}_{0.7} \mathrm{GnP}_{1.0}$ at initial, 500 and 1000 cycles are almost identical at potentials above $-0.05 \mathrm{~V}$; below $-0.05 \mathrm{~V}$, the curves are only slightly separated. However, in Figure S6, the $\mathrm{WSoy}_{0.7}$ and $\mathrm{WGnP}_{1.0}$ catalysts show increased overpotentials after 500 and 1000 cycles of the deterioration test. Without graphene, the stability performance of the $\mathrm{WSoy}_{0.7}$ was slightly worse than that of the $\mathrm{WSoy}_{0.7} \mathrm{GnP}_{1.0}$. On the other hand, without soybean in the precursor mixture, the $\mathrm{WGnP}_{1.0}$ deteriorated significantly after 500 and 1000 potential cycles. Therefore, the $\mathrm{WSoy}_{0.7} \mathrm{GnP}_{1.0}$ displays better electrochemical stability performance than either the $\mathrm{WSoy}_{0.7}$ or the $\mathrm{WGnP}_{1.0}$. In addition, chronopotentiometric measurements of the $\mathrm{WSoy}_{0.7} \mathrm{GnP}_{1.0}$ at a current density of 10 and $20 \mathrm{~mA} \mathrm{~cm}{ }^{-2}$ are shown in Figure 5(b). The overpotentials at both constant current densities were fairly constant during electrolysis for 24 hours. As demonstrated in our previous research, ${ }^{4}$ the stable electrochemical performance of the $\mathrm{WSoy}_{0.7} \mathrm{GnP}_{1.0}$ is also considered to result from the presence of the stabilizer $\mathrm{WN}$ in the catalyst.

In conclusion, we have developed a low-cost and high-performance tungsten-based catalyst by sintering AMT, soybean powder and graphene nanoplatelets at $850{ }^{\circ} \mathrm{C}$. After mass 
ratio optimization, the $\mathrm{WS}_{0.7} \mathrm{GnP}_{1.0}$ demonstrated the best electrochemical HER performance with the smallest overpotential $\left(\eta_{10}=0.105 \mathrm{~V}\right)$ among all the $\mathrm{WSoy}_{\mathrm{x}} \mathrm{GnP}_{\mathrm{y}}$ catalysts examined.

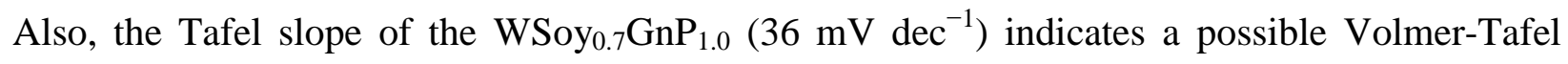
reaction pathway. The low charge transfer resistance $(9 \Omega)$ and high double-layer capacitance $\left(49.0 \mathrm{mF} \mathrm{cm}^{-2}\right.$ ) of the $\mathrm{WSoy}_{0.7} \mathrm{GnP}_{1.0}$ suggest that graphene improves charge transfer kinetics and increases the number of catalytic reaction sites. In addition, the $\mathrm{WS}_{0.7} \mathrm{GnP}_{1.0}$ exhibited excellent stability in the electrochemical HER after a 1000 potential cycle test as well as the significant long-term durability of chronopotentiometric water splitting up to 24 hours. Owing to its excellent kinetics and stability properties, the $\mathrm{WS}_{0.7} \mathrm{GnP}_{1.0}$ catalyst stands out as one of the few top-performance candidates among all the tungsten-based catalysts for the electrochemical HER.

\section{Acknowledgement}

The TEM/HRTEM studies were carried out at the Center for Functional Nanomaterials, Brookhaven National Laboratory (BNL). The work at BNL was carried out under contract DESC00112704 with the U.S. Department of Energy, Office of Science, Office of Basic Energy Sciences.

\section{References}

(1) A. B. Laursen, S. Kegnas, S. Dahl and I. Chorkendorff, Energy Environ. Sci., 2012, 5, 55775591.

(2) A. Kudo and Y. Miseki, Chem. Soc. Rev., 2009, 38, 253-278.

(3) L. Cheng, W. J. Huang, Q. F. Gong, C. H. Liu, Z. Liu, Y. G. Li and H. J. Dai, Angew. Chem. Int. Ed., 2014, 53, 7860-7863.

(4) W. F. Chen, M. S. Schneider, K. Sasaki, C.H. Wang, J. Schneider, S. Iyer, S. Iyer, Y. Zhu, J. T. Mucherman and E. Fujita, ChemSusChem, 2014, 7, 2414-2418.

(5) W. F. Chen, C. H. Wang, K. Sasaki, N. Marinkovic, W. Xu, J. T. Mucherman, Y. Zhu and R. R. Adzic, Energy Environ. Sci., 2013, 6, 943-951.

(6) H. T. Wang, D. S. Kong, P. Johanes, J. J. Cha, G. Y. Zheng, K. Yan, N. Liu and Y. Cui, Nano Lett., 2013, 13, 3426-3433. 
(7) Y. Zhou, Z. Xie, K. A. Brown, D. J. Park, X. Zhou, P. Chen, M. Hirtz, Q. Y. Lin, V. P. Dravid, G. C. Schatz, Z. Zheng and C. A. Mirkin, Small. 2015, 11, 913-917.

(8) A. S. Daniel, R. Caroline, F. Meng, A. Forticaux, R. J. Hamers and S. Jin, Energy Environ. Sci., 2014, 7, 2608-2613.

(9) W. F. Chen, J. T. Muckerman and E. Fujita, Chem. Commun., 2013, 49, 8896-8909.

(10) T. F. Jaramillo, K. P. Jorgensen, J. Bonde, J. H. Nielsen, S. Horch and I. Chorkendorff, Science, 2007, 317, 100-102.

(11) W. C. Sheng, M. Myint, J. G. Chen and Y. S. Yan, Energy Environ. Sci., 2013, 6, 15091512.

(12) J. Turner, G. Sverdrup, M. K. Mann, P. C. Maness, B. Kroposki, M. Ghirardi, R. J. Evans and D. Blake, Int. J. Energy Res., 2008, 32, 379-407.

(13) D. Voiry, H. Yamaguchi, J. Li, R. Silva, D. Alves, T. Fujita, M. Chen, T. Asefa, V. B. Shenoy, G. Eda and M. Chhowalla, Nat. Mater., 2013, 12, 850-855.

(14) J. Lin, Z. Peng, G. Wang, D. Zakhidov, E. Larios, M. Yacaman and J. M. Tour, Adv. Energy Mater., 2014, 4, 1301875.

(15) C. L. Choi, J. Feng, Y. Li, J. Wu, A. Zak, R. Tenne and H. J. Dai, Nano Res., 2013, 6, 921928.

(16) K. Xu, F. M. Wang, Z. X. Wang, X. Y. Zhan, Q. S. Wang, Z. Z. Cheng, M. Safdar and J. He, ACS Nano, 2014, 8, 8468-8476.

(17) J. M. Velazquez, F. H. Saadi, A. P. Pieterick, J. M. Spurgeon, M. P. Soriaga, B. S. Brunschwig and N. S. Lewis, J. Electroanal. Chem., 2014, 716, 45-48.

(18) Z. H. Pu, Q. Liu, A. M. Asiri and X. Sun, ACS Appl. Mater. Interfaces, 2014, 6, $21874-$ 21879.

(19) J. M. McEnaney, C. Crompton, J. F. Callejas, E. J. Popczun, C. G. Read, N. S. Lewis and R. E. Schaak, Chem. Commun., 2014, 50, 11026-11028.

(20) S. T. Hunt, T. Nimmanwudipong and Y. Roman-Leshkov, Angew. Chem. Int. Ed., 2014, 53, 5131-5136.

(21) D. V. Esposito and J. G. Chen, Energy Environ. Sci., 2011, 4, 3900-3912.

(22) T. G. Kelly and J. G. Chen, Chem. Soc. Rev., 2012, 41, 8021-8034. 
(23) D. V. Esposito, S. T. Hunt, Y. C. Kimmel and J. G. Chen, J. Am. Chem. Soc., 2012, 134, 3025-3033.

(24) H. Fei, Y. Yang, X. Fan, G. Wang, G. Ruan and J. M. Tour, J. Mater. Chem. A, 2015, 3, 5798-5804.

(25) R. B. Levy and M. Boudart, Science, 1973, 181, 547-549.

(26) L. H. Bennett, J. R. Cuthill, A. J. McAlister, N. E. Erickson and R. E. Watson, Science, 1974, 184, 563-565.

(27) D.R. McIntyre, G.T. Burstein and A. Vossen, J. Power Sources, 2002, 107, 67-73.

(28) J. G. Chen, Chem. Rev., 1996, 96, 1477-1498.

(29) W. F. Chen, S. Iyer, S. Iyer, K. Sasaki, C. H. Wang, Y. Zhu, J. T. Muckerman and E. Fujita, Energy Environ. Sci., 2013, 6, 1818-1826.

(30) F. K. Meng, J. T. Li, S. K. Cushing, J. Bright, M. J. Zhi, J. D. Rowley, Z. L. Hong, A. Manivannan, A. D. Bristow and N. Q. Wu, ACS Catal., 2013, 3, 746-751.

(31) F. K. Meng, J. T. Li, S. K. Cushing, M. J. Zhi and N. Q. Wu, J. Am. Chem. Soc., 2013, 135, 10286-10289.

(32) I. V. Lightcap, T. H. Kosel and P. V. Kamat, Nano Lett., 2010, 10, 577-583.

(33) G. Q. Lu and J. T. Yates, Chem. Rev., 1995, 95, 735-758.

(34) C. L. McCrory, S. Jung, I. M. Ferrer, S. M. Chatman, J. C. Peters and T. F. Jaramillo, J. Am. Chem. Soc., 2015, 137, 4347-4357.

(35) R. Ganesan and J. S. Lee, Angew. Chem. Int. Ed., 2005, 44, 6557-6560.

(36) N. Ji, T. Zhang, M. Zheng, A. Wang, H. Wang, X. Wang and J. G. Chen, Angew. Chem. Int. Ed., 2008, 47, 8510-8513. 


\title{
Supporting Information
}

\section{Biomass-Derived High-Performance Tungsten-Based Electrocatalyst on Graphene for Hydrogen Evaluation}

\author{
Fanke Meng, ${ }^{a}$ Enyuan Hu, ${ }^{a}$ Lihua Zhang, ${ }^{b}$ Kotaro Sasaki, ${ }^{a}, *$ \\ James T. Muckerman, ${ }^{a}$ and Etsuko Fujita ${ }^{a}{ }_{*}$ \\ ${ }^{a}$ Chemistry Department, Brookhaven National Laboratory, Upton, New York, 11973, USA. \\ ${ }^{b}$ Center for Functional Nanomaterials, Brookhaven National Laboratory, Upton, New York \\ 11973, USA
}




\section{Experimental}

\section{Synthesis of tungsten-based composite catalysts}

Graphene-supported tungsten-based composites (WSoy $\mathrm{GnP}_{\mathrm{y}}, \mathrm{x}$ and y are mass ratios of the soybean and graphene nanoplatelets) were prepared by sintering powdered mixtures of graphene nanoplatelets $\left(\mathrm{GnP}, \mathrm{xGnP}^{\circledR} \mathrm{C}-750\right.$ from XG Sciences) with ammonium tungstate (AMT, $\left(\mathrm{NH}_{4}\right)_{10} \mathrm{H}_{2}\left(\mathrm{~W}_{2} \mathrm{O}_{7}\right)_{6} \cdot 4 \mathrm{H}_{2} \mathrm{O}$, Aldrich) and soybean (organic yellow dry soybeans supplied by the Whole Food Market, Inc.) powder.

The mass ratio of soybean over AMT was optimized firstly. The detailed procedure is described as follows. First, the soybean was ground to a powder and mixed with AMT. The mass ratios of soybean over AMT were 0.2, 0.5, 0.7, 1.0, and 2.0 respectively. For a typical example, $200 \mathrm{mg}$ of AMT was mixed with $40 \mathrm{mg}, 100 \mathrm{mg}, 140 \mathrm{mg}, 200 \mathrm{mg}$, and $400 \mathrm{mg}$ of soybean respectively. Second, the mixtures were added into deionized (DI) water and ultrasonicated for $40 \mathrm{~min}$ to form uniform suspensions. Third, the suspensions were dried in an oven at $90{ }^{\circ} \mathrm{C}$ overnight. Fourth, the dried powders were sintered at $850{ }^{\circ} \mathrm{C}$ in argon for $2 \mathrm{hrs}$ in a quartz tube furnace to obtain black catalyst powders for the following experiments. Among all the samples

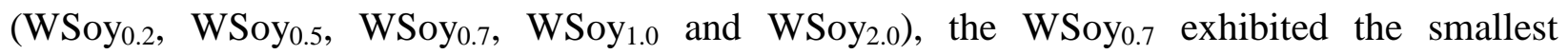
overpotential $\left(\eta_{10}\right)$. Consequently, the content of graphene was tuned in the order of WSoy $_{0.7} \mathrm{GnP}_{0.5}$, WSoy ${ }_{0.7} \mathrm{GnP}_{1.0}$ and $\mathrm{WSoy}_{0.7} \mathrm{GnP}_{2.0}$. As a comparison, $\mathrm{WGnP}_{1.0}$ was synthesized using the same method.

\section{Electrochemical measurements}

The electrochemical polarization curves of the catalyst samples were measured with VersaSTAT 3 Potentiostate (Princeton Applied Research) in a three-electrode configuration cell, in which the catalyst, platinum and $\mathrm{Ag} / \mathrm{AgCl} / \mathrm{KCl}(3 \mathrm{M})$ acted as working electrode, counter electrode and reference electrode, respectively. All potentials were quoted with respect to reversible hydrogen electrode (RHE), and all the polarization curves were $i R$-corrected according to ohmic resistance obtained in the electrochemical impedance spectroscopy (EIS) measurement. Typically, $10 \mathrm{mg}$ of catalyst powder was mixed with 5 drops of $20 \%$ Nafion dispersion (DuPont) to form homogenous slurry. The slurry was pasted onto $1 \mathrm{~cm}^{2}$ carbon paper (Toray TGP-H-060. The size of the carbon paper was $1 \mathrm{~cm} \times 3 \mathrm{~cm}$, on which a $1 \times 1 \mathrm{~cm}^{2}$ area was exposed for slurry loading). After dried, the carbon paper loaded with catalyst was immersed into 
$0.1 \mathrm{M} \mathrm{HClO}_{4}$ (aq.) electrolytes for electrochemical experiments. As a reference, the $\mathrm{Pt} / \mathrm{C}$ was loaded onto a carbon paper electrode (diameter of $3 \mathrm{~mm}$ ). The Pt/C (plot (g) in Figure 1(a)) was commercially available from BASF Inc. (20\% HP Pt on Vulcan XC-72R). The electrolyte solution was always bubbled with $\mathrm{H}_{2}$ during the measurements.

The polarization curves for the hydrogen evolution reaction (HER) were obtained at a scan rate of $2 \mathrm{mV} \mathrm{s}^{-1}$. The long-term stability tests were performed by potential cycling between $-0.5 \mathrm{~V}$ and $+0.3 \mathrm{~V}$ at a scan rate of $200 \mathrm{mV} \mathrm{s}^{-1}$. The EIS measurements were conducted with a frequency from $100000 \mathrm{~Hz}$ to $0.01 \mathrm{~Hz}$ to determine ohm resistance $\left(R_{\mathrm{s}}\right)$ and charge-transfer resistance $\left(R_{\mathrm{ct}}\right)$. The double layer capacitances were tested using a glassy carbon electrode with a sample loading of $10 \mathrm{mg} \mathrm{cm}^{-2}$.

\section{Material Characterization}

The morphology of the samples was obtained by transmission electron microscope (TEM, JEOL JEM 2100F). To prepare the TEM sample, $2 \mathrm{mg}$ of catalyst was dissolved into 5 $\mathrm{mL}$ ethanol by ultrasonication for half minute to achieve a uniform suspension. Then, the suspension was dropped onto a carbon grid (Ted Pella, Inc.), which was thereafter dried in air for observation under TEM. The crystal structure and phase composition were obtained by a highresolution TEM (HRTEM) and X-ray diffraction (XRD, Rigaku Ultima III) with Cu K $\alpha$ radiation $\left(\lambda=1.542 \AA\right.$ ). The three phases in the catalysts were assigned to be $\alpha-\mathrm{W}_{2} \mathrm{C}, \delta$-WC, and WN with the major XRD peaks at $39.6^{\circ}(101)$ (JCPDS: 35-0776), 35.6 ${ }^{\circ}$ (100) (JCPDS: 72-0097), 37.7 (111) (JCPDS: 65-2898), respectively. Thermogravimetric Analysis (TGA, Perkin Elmer Diamond) was conducted by heating the samples in oxygen flow $(100 \mathrm{sccm})$ up to $950{ }^{\circ} \mathrm{C}$ from room temperature. Then, the samples were kept in oxygen at $950{ }^{\circ} \mathrm{C}$ for $10 \mathrm{~min}$ to ensure that all the samples were changed to tungsten oxide. The contents of each phase in the catalysts were

calculated by using Rietveld-refined XRD spectra and TGA results. ${ }^{1}$ The method of Rietveld refinement is briefly introduced in the following experimental section 4 .

\section{Rietveld refinement of the XRD data}

Rietveld refinement was carried out using the software GSAS-EXPGUI. ${ }^{2,3}$ The refinement is based on the model that physically describes the peak position and peak intensity and semi-empirically describes the peak shape. The peak position is mainly determined by the 
lattice constant and x-ray wavelength according to Bragg's law and the peak intensity is mainly determined by atomic positions, atomic vibrations and phase fraction. The peak shape is modeled using a pseudo-Voigt function which is a linear combination of Gaussian function and Lorentzian function. Physical parameters and parameters of describing the peak shape are refined to yield the most satisfactory description of the whole XRD pattern. Phase fraction information is thus obtained.

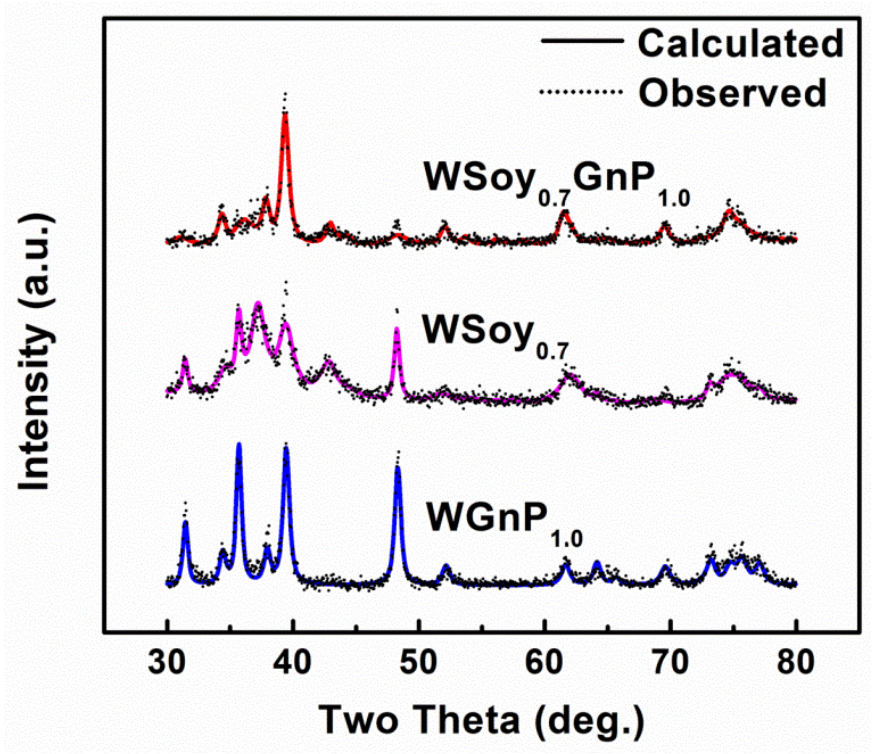

Figure S1. XRD spectra of the samples and Rietveld refined spectra

Table S1. Mass ratio of the $\mathrm{W}_{2} \mathrm{C}, \mathrm{WC}$ and $\mathrm{WN}$ phases in $\mathrm{WSoy}_{0.7} \mathrm{GnP}_{1.0}$, $\mathrm{WSoy}_{0.7}$ and $\mathrm{WGnP}_{1.0}$.

\begin{tabular}{cccc}
\hline Sample & WSoy $_{0.7} \mathrm{GnP}_{1.0}$ & WSoy $_{0.7}$ & WGnP $_{1.0}$ \\
\hline $\mathrm{W}_{2} \mathrm{C}$ & 0.74 & 0.44 & 0.46 \\
$\mathrm{WC}$ & 0.18 & 0.46 & 0.54 \\
$\mathrm{WN}$ & 0.08 & 0.1 & -- \\
\hline
\end{tabular}




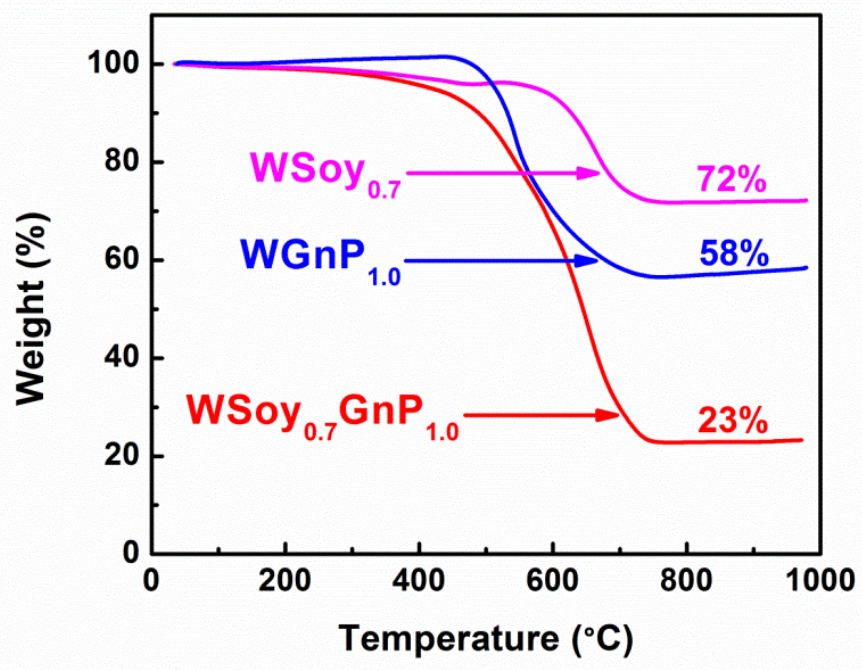

Figure S2. TGA thermogramms of the $\mathrm{WSoy}_{0.7} \mathrm{GnP}_{1.0}$, $\mathrm{WSoy}_{0.7}$ and $\mathrm{WGnP}_{1.0}$ samples. 

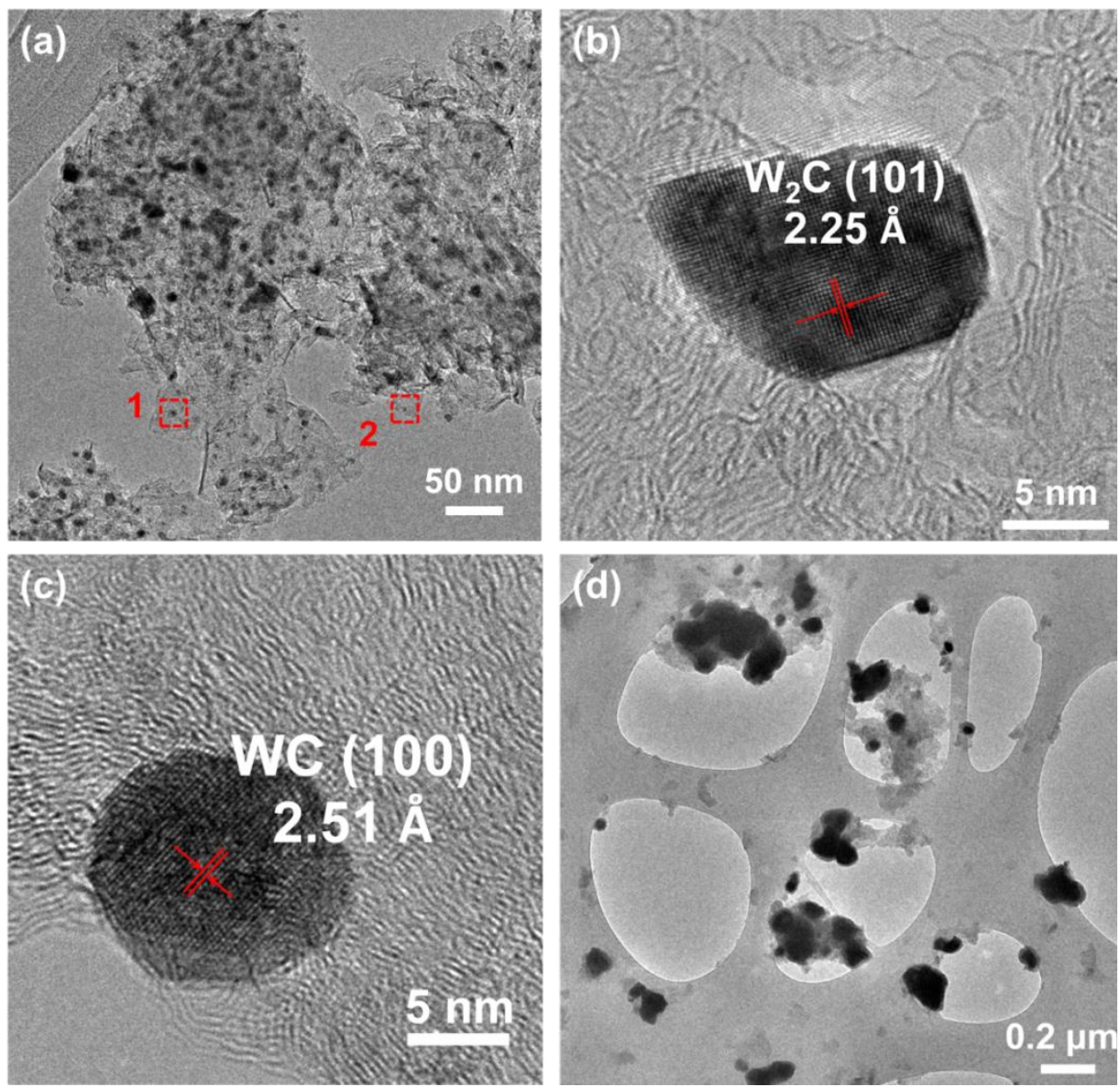

Figure S3. TEM and HRTEM images of the $\mathrm{WGnP}_{1.0}$ (a)-(c), and WSoy $_{0.7}(\mathrm{~d})$. The HRTEM images in (b) and (c) show the area of the red squares labeled 1 and 2, respectively, in image (a) indicating decoration of $\mathrm{W}_{2} \mathrm{C}$ and $\mathrm{WC}$ nanoparticles on the graphene nanoplatelets.
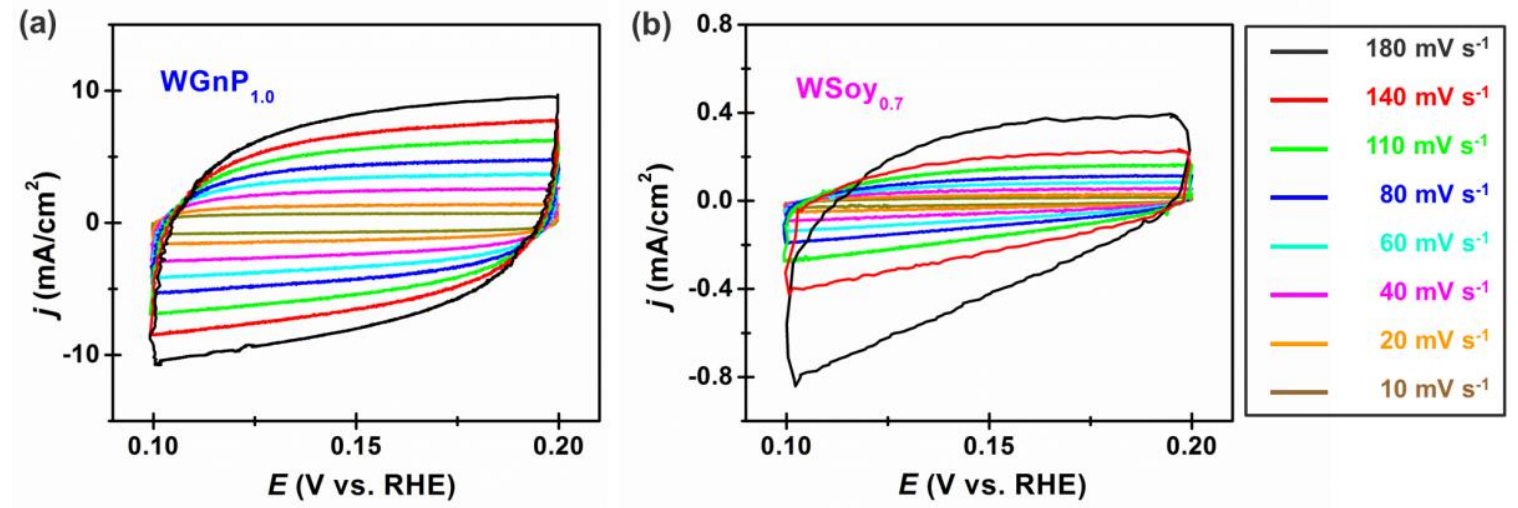

Figure S4. Cyclic voltammetry curves of the $\mathrm{WGnP}_{1.0}$ and $\mathrm{WSoy}_{0.7}$ in the region of $0.1-0.2 \mathrm{~V}$. 


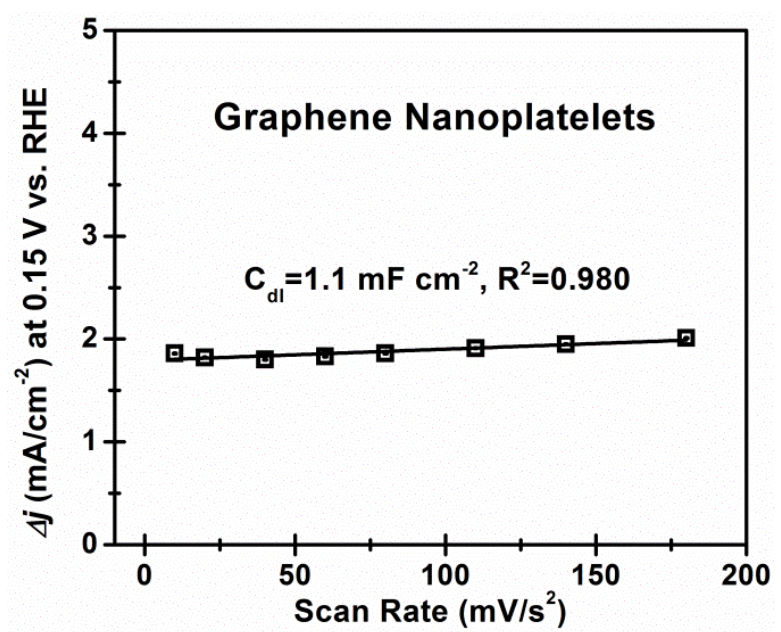

Figure S5. Liner fitting of the capacitive current of the graphene nanoplatelets vs. the scan rate to obtain the $C_{\mathrm{dl}}$.
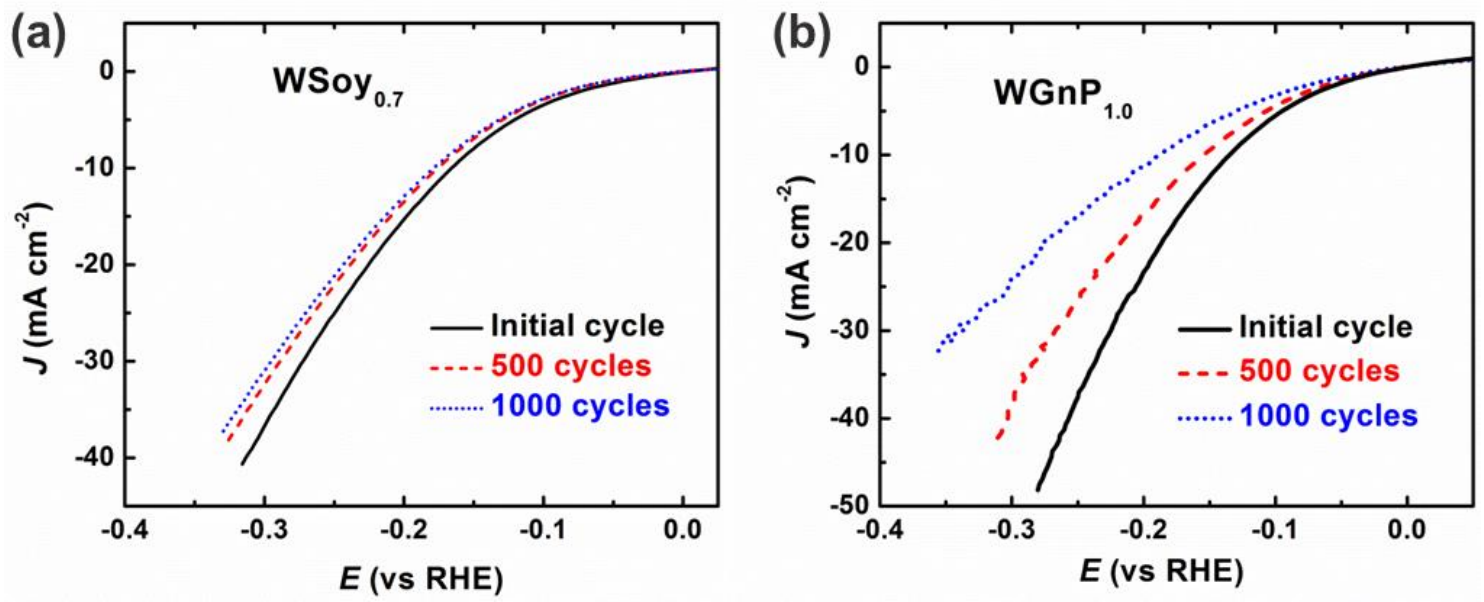

Figure S6. Polarization curves of the $\mathrm{WSoy}_{0.7}$ and $\mathrm{WGnP}_{1.0}$ catalysts before and after 500 and 1000 cycles at potentials between $-0.5 \mathrm{~V}$ and $+0.3 \mathrm{~V}$ with a scan rate of $200 \mathrm{mV} \mathrm{s}^{-1}$. 
Table S2. Comparison of different W-based HER electrocatatlysts available from literatures.

\begin{tabular}{|c|c|c|c|c|c|c|}
\hline Catalyst & $\begin{array}{l}\text { Overpotential } \\
\qquad\left(\eta_{10}\right), \mathrm{mV}\end{array}$ & $\begin{array}{l}\text { Tafel slope, } \\
\mathrm{mV} \operatorname{dec}^{-1}\end{array}$ & $\begin{array}{c}\text { Exchange Current } \\
\text { Density, } \\
10^{-2} \mathrm{~mA} \mathrm{~cm}^{-2}\end{array}$ & $\mathrm{R}_{\mathrm{ct}}, \Omega$ & Stability & Ref. \\
\hline WSoy $_{0.7} \mathrm{GnP}_{1.0}$ & 105 & 36 & 6.3 & $\begin{array}{c}10.7 \\
@ 100 \mathrm{mV}\end{array}$ & $\begin{array}{l}1000 \text { cycles, } 24 \mathrm{hrs} \\
\text { Chronopotentialmetric } \\
\text { electrolysis, stable }\end{array}$ & $\begin{array}{l}\text { This } \\
\text { study }\end{array}$ \\
\hline $\begin{array}{l}\alpha-\text { WC/carbon } \\
\text { black }\end{array}$ & 260 & N/A & N/A & N/A & 3000 cycles,stable & 4 \\
\hline $\mathrm{W}_{2} \mathrm{C}$ microsphere & $\sim 170$ (a) & 118 & 28.1 & N/A & N/A & 5 \\
\hline Commercial WC & $\sim 300$ (a) & 73 & 1.8 & N/A & N/A & 5 \\
\hline $\mathrm{W}_{0.5} \mathrm{Ani} / \mathrm{GnP}$ & 120 & $68.6(b)$ & 3.8 & $12.7 @ 100$ mV & 10000 cycles, stable & 1 \\
\hline $\mathrm{W}_{2} \mathrm{C} / \mathrm{GnP}$ & 186 & 64.7 (b) & 2.4 & 15.6@100 mV & $\begin{array}{c}5000 \text { cycles, } \\
\text { not stable }\end{array}$ & 1 \\
\hline Bulk $\mathrm{W}_{2} \mathrm{C}$ & 336 & 88.0 (b) & 0.065 & 1750@100 mV & N/A & 1 \\
\hline WN & $>500$ & N/A & N/A & N/A & $\begin{array}{c}5000 \text { cycles, } \\
\text { stable }\end{array}$ & 1 \\
\hline Thin film $\mathrm{W}_{2} \mathrm{C}$ & $>300(\mathrm{c})$ & 69 & 0.02 & N/A & N/A & 6 \\
\hline Thin film WC & $>400(\mathrm{c})$ & 91 & 0.25 & N/A & N/A & 6 \\
\hline $\mathrm{WS}_{2}$ nanosheets & $\sim 160$ & 72 & 0.25 & N/A & 1000 cycles, stable & 7 \\
\hline $\begin{array}{c}\text { Exfoliated 1T } \\
\mathrm{WS}_{2}\end{array}$ & $\sim 260$ (a) & $\sim 55$ & 2.0 & $\begin{array}{c}>250 @ 100 \\
\mathrm{mV}\end{array}$ & $>10000$ cycles, stable & 8 \\
\hline $\begin{array}{l}\mathrm{WS}_{2} / \mathrm{rGO} \text { hybrid } \\
\text { nanosheets }\end{array}$ & $\sim 260$ (a) & 58 & $<0.1(\mathrm{~d})$ & $\sim 200$ & N/A & 9 \\
\hline $\begin{array}{c}\text { metallic } \mathrm{WS}_{2} \\
\text { nanosheets }\end{array}$ & 142 & 70 & N/A & $5 @ 250 \mathrm{mV}$ & $\begin{array}{l}500 \text { cycles, slight loss } \\
\text { in catalytic activity }\end{array}$ & 10 \\
\hline $\mathrm{WS}_{2}$ nanoflakes & $\sim 150$ (a) & 48 & N/A & N/A & $\begin{array}{c}10000 \text { cycle, slight } \\
\text { loss in catalytic } \\
\text { activity }\end{array}$ & 11 \\
\hline $\mathrm{WS}_{2}$ nanoribbons & 225 & 68 & 1.25 & $\begin{array}{c}38 @ 250 \mathrm{mV}, \\
>2000 @ 100 \\
\mathrm{mV}\end{array}$ & 1000 cycle, stable & 12 \\
\hline $\begin{array}{l}\mathrm{WSe}_{2} \text { on carbon } \\
\text { fiber paper }\end{array}$ & 300 & 77.4 & N/A & N/A & 15000 cycle, stable & 13 \\
\hline $\mathrm{WSe}_{2}$ & $\sim 350$ (a) & 99 & 0.3 & $624 @ 128$ mV & $\begin{array}{c}\text { Potentiostatic } \\
\text { electrolysis for } 7000 \mathrm{~s} \text {, } \\
\text { stable }\end{array}$ & 14 \\
\hline
\end{tabular}




\begin{tabular}{|c|c|c|c|c|c|c|}
\hline $\mathrm{W}\left(\mathrm{S}_{0.48} \mathrm{Se}_{0.52}\right)_{2}$ & $\sim 260$ (a) & 105 & 2.9 & 204@128 mV & $\begin{array}{c}\text { Potentiostatic } \\
\text { electrolysis for } 7000 \mathrm{~s} \text {, } \\
\text { stable }\end{array}$ & 14 \\
\hline \multirow[t]{2}{*}{ Amorphous WP } & $\sim 120$ (a) & 54 & 4.5 & N/A & 500 cycles & 15 \\
\hline & & & & & $\begin{array}{c}18 \mathrm{hr}, 100 \mathrm{mV} / \mathrm{s} \\
\text { stable }\end{array}$ & \\
\hline $\begin{array}{l}\text { P-modified } \\
\text { WN/rGO }\end{array}$ & 85 & 54 & 35 & N/A & $\begin{array}{c}5000 \text { cycles, slight loss } \\
\text { in catalytic activity }\end{array}$ & 16 \\
\hline $\begin{array}{l}\text { WC on vertically } \\
\text { aligned CNTs }\end{array}$ & 145 & 72 & $\sim 10(\mathrm{~d})$ & N/A & $\begin{array}{l}1000 \text { cycles, slight loss } \\
\text { in catalytic activity }\end{array}$ & 17 \\
\hline
\end{tabular}

(a) The overpotential $\left(\eta_{10}\right)$ was estimated from $J V$ polarization curves.
(b) The Tafel slope was obtained from plots of $E$ vs. $\log \left(R_{\mathrm{ct}}\right)^{-1}$.
(c) The overpotential $\left(\eta_{10}\right)$ was estimated from Tafel plots.
(d) The exchange current density was estimated from Tafel plots.

\section{References}

(1) W. F. Chen, M. S. Schneider, K. Sasaki, C. H. Wang, J. Schneider, S. Iyer, S. Iyer, Y. Zhu, J. T. Mucherman and E. Fujita, ChemSusChem, 2014, 7, 2414-2418.

(2) "Gsas." General Structure Analysis System, A.C. Larson, R.B. Von Dreele. LANSCE, MSH805, Los Alamos, New Mexico (1994).

(3) EXPGUI, a graphical user interface for GSAS, B.H. Toby, J. Appl. Crystallogr., 2001, 34 , 210-213.

(4) S. T. Hunt, T. Nimmanwudipong and Y. Roman-Leshkov, Angew. Chem. Int. Ed., 2014, 53, 5131-5136.

(5) D. J. Ham, R. Ganesan and J. S. Lee, Int. J. Hydrogen Energy, 2008, 33, 6865-6872.

(6) D. V. Esposito, S. T. Hunt, Y. C. Kimmel and J. G. Chen, J. Am. Chem. Soc., 2012, 134, 3025-3033.

(7) Z. Wu, B. Fang, A. Bonakdarpour, A. Sun, D. P. Wilkinson and D. Wang, Appl. Catal., B., 2012, 125, 59-66.

(8) D. Voiry, H. Yamaguchi, J. Li, R. Silva, D. Alves, T. Fujita, M. Chen, T. Asefa, V. B. Shenoy, G. Eda and M. Chhowalla, Nat. Mater., 2013, 12, 850-855. 
(9) J. Yang, D. Voiry, S. J. Ahn, D. Kang, A. Kim, M. Chhowalla and H. Shin, Angew. Chem. Int. Ed., 2013, 52, 13751-13754.

(10) A. S. Daniel, C. R. English, F. Meng, A. Forticaux, R. J. Hamers and S. Jin, Energy Environ. Sci., 2014, 7, 2608-2613.

(11) L. Cheng, W. J. Huang, Q. F. Gong, C. H. Liu, Z. Liu, Y. G. Li and H. J. Dai, Angew. Chem. Int. Ed., 2014, 53, 7860-7863.

(12) J. Lin, Z. Peng, G. Wang, D. Zakhidov, E. Larios, M. Yacaman and J. M. Tour, Adv. Energy Mater., 2014, 4, 1301875.

(13) H. T. Wang, D. S. Kong, P. Johanes, J. J. Cha, G. Y. Zheng, K. Yan, N. Liu and Y. Cui, Nano Lett., 2013, 13, 3426-3433.

(14) K. Xu, F. M. Wang, Z. X. Wang, X. Y. Zhan, Q. S. Wang, Z. Z. Cheng, M. Safdar and J. He, ACS Nano, 2014, 8, 8468-8476.

(15) J. M. McEnaney, C. Crompton, J. F. Callejas, E. J. Popczun, C. G. Read, N. S. Lewis and R. E. Schaak, Chem. Commun., 2014, 50, 11026-11028.

(16) H. Yan, C. Tian, L. Wang, A. Wu, M. Meng, L. Zhao, H. Fu, Angew. Chem. Int. Ed., 2015, 54, 6325-6329.

(17) X. Fan, H. Zhou, X. Guo, ACS Nano, 2015, 9, 5125-5134. 